\section{El Bajo de Santa Fé}

A DETAMLED investigation of a seasonal swamp close to the Maya site of Tikal, Guatemala, was undertaken to find evidence for the collapse of the civilization about A.D. 900 (Trans. Amer. Phil. Soc. N.S., 53, Part 7: El Bajo de Santa $F e ́$. By Ursula M. Cowgill and G. E. Hutchinson. Pp. 51. Philadelphia: American Philosophical Society, 1963. 1.75 dollars). The report incorporates descriptions of the geology, climate, vegetation and previous investigations of the area of flatlands predominated by logwood. The bajos lie between sea-level and $150 \mathrm{~m}$, with a mean annual rainfall of about $150 \mathrm{~cm}$, and mean minimum and maximum temperatures of $19^{\circ}$ and $31^{\circ} \mathrm{C}$. The plant cover is mixed xerophytic forest with a luxuriant growth of logwood (Haematoxylum campechianum). The Bajo de Santa $\mathrm{F} e$ is about $100 \mathrm{sq} . \mathrm{km}$. in area, and a pit was dug at a point free from obvious contamination or ground disturbance and about $1 \mathrm{~km}$. from the nearest forest. The surface $120 \mathrm{em}$ comprised a dark brown clay, the colour becoming lighter with depth. Live roots were found to $145 \mathrm{~cm}$ and root remains down to $5 \mathrm{~m}$. A car. bonaceous material of unknown nature was encrusted with gypsum at $500-511 \mathrm{~cm}$ and gave a radiocarbon date

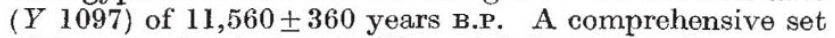
of data on chemical and differential thermal analyses, and of X-ray diffractometer tracings, for samples at different depths and for the residue from the scarp limestone, as well as the figures for the composition of water samples from the area, are examined statistically. The evidence does not support the hypothesis that the swamp developed by choking of a lake system by eroded soil arising from Maya agriculture; the features of the sediment suggest rather a slow deposition in swamp conditions such as exist to-day. There is an appendix by S. E. Sanders on a petrographic examination of chert nodules and another by O. Joensuu on the complete chemical analysis of samples from the pit.

\section{Uses of Papaya in India}

PAPAyA is indigenous to tropical America and is very popular as a fruit in the United States, Canada and several European countries. In India, where it is produced in almost every state, it can be justly described as the common man's fruit. As papaya is very susceptible to spoilage even under favourable conditions of temperature and humidity, the problems of storage and marketing of the fruit in India are even more serious than in the case of most other fruits. With this in mind, the Central Food Technological Research Institute, Mysore, has directed special attontion to the integrated utilization of the fruit at various stages of maturity (Industrial Monograph, No. 2: Papaya. Pp. vi+4l. Mysore: Central Food Technological Research Institute, 1963). The major contribution of the Institute relates to the production of papain of high activity, which is also maintained over a long period of storage. Investigations have covered the extrac. tion of pectin from unripe papaya and the utilization of the pulp from the raw and the ripe fruit for various processed products, such as pickle, preserves and confectionery. The monograph covors nutritional quality, cultivation practices, varieties of commercial importance, marketing and various technological and industrial aspects. Special sections devoted to individual products include compositional data, recipes and methods of preparation, and in a few instances flow sheet diagrams. The model schemes outlined in the appendixes cover the production costs of such products as papain, pectin, papaya toffoes, cereal flakes and custard powder.

\section{Estrogenically Active Steroid Extracts from Grass- lands}

Over the past twenty-five years experiments have been carried out by African Explosives and Chemical Industries, Ltd., on the fertilization of natural veld and sown pastures. One of the findings has been improvement in the quality of the herbage following fertilizing with phosphatic and nitrogenous fertilizers. Beef animals made more rapid gains when grazing on fertilized veld or pastures. The improvement in the protein and phosphate contents of the herbage, though substantial, did not appear to provide adequate explanation of the improved performance of the beef animals grazing the fertilized pastures, and an unknown factor was suspected. The analyses, over seven years, of milk produced by cows grazing in fertilized veld showed increases in solids and butterfat when compared with the milk from similar cows grazing on unfertilized veld. In Britain, G. S. Pope and S. J. Folley have shown that ostrogenic hormone administered to Dairy Shorthorn cows brought about increases in the butterfat and solids-not-fat of the milk. T. M. Clegg found that œestrogenic hormones resulted in higher efficiency of feed utilization when implanted. injected subcutaneously, or administered orally to beef animals.

The experiments carried out in Africa by R. E. Altona and T. J. Tilley were conducted to investigate hormone activity in pure grass pastures (South African Journal of Science, 59, No. 12; December 1963). Hay was cut in fertilized and unfertilized veld. The grasses making up the hay from the fertilized veld were mainly species of Eragrostis, while the unfertilized hay consisted of numerous genera of which Trachypogon spicatus, Tristachya hispida and Elionurus argentus were dominant. Hay was also cut in fertilized Eragrostis curvula pastures.

The results indicate a positive œstrogenic reaction from hay cut from fertilized veld and also from hay eut from fertilized Eragrostis pasture. Unfertilized veld hay gave negative results. Whether the cstrogenic activity was brought about by the fertilizing of the pastures or was due to the occurrence of Eragrostis, which did not occur to any degree in the unfertilized veld, is not known. An attempt was made to evaluate the effect of different levels of nitrogenous fertilizer on the œstrogenic activity of Eragrostis curvula. The results gave no clear-cut answer, but indicated that applied nitrogen might influence the œstrogenic activity of a pasture.

\section{The Association of Applied Biologists}

THE following have been elected honorary officers of the Association of Applied Biologists for the session 1964-65: President, Prof. J. H. Western; Vice-President, M. J. Way; President-Elect, F. C. Bawden; Treasurer, Dr. F. Raw; General Secretary, Dr. F. T. Last; Programme Secretary, F. G. H. Lupton; Editor, R. W. Marsh; Assistant Editor, Dr. I. Thomas. New members of Council elected were: Dr. N. H. E. Gibson, Dr. D. L. Gunn, Dr. F. L. Milthorpe, Dr. T. W. Tinsley.

\section{The Zoological Society of London Awards}

THE following awards of the Zoological Society of London were presented by H.R.H. the Duke of Edinburgh, president of the Society, at the annual general meeting on May 4: The Gold Medal, to the late Mr. J. Cotton, in recognition of the outstanding help he gave to the Society in its efforts to rebuild the Zoological Gardens at Regent's Park (the announcement of this award was made on December 4, 1963). The Scientific Medal (awarded to persons under forty years of age for scientific merit and distinguished work in zoology), jointly to Dr. L. Brent, National Institute for Medical Research, Mill Hill, N.W.7, who has worked with Dr. P. B. Medawar and Dr. R. E. Billingham on transplantation immunology; to Dr. P. H. Greenwood, principal scientific officer, Department of Zoology, British Museum (Natural History), for outstanding work on the life histories of East African freshwater fishes and in particular on the taxonomy and relationships of African sfecies of cichlid fishes; and to Dr. Janet Harker, of the Department of Zoology. Univer- 